\title{
Editorial
}

\section{Fauna norvegica - online and open access}

\author{
Torkild Bakken
}

Bakken T. 2009. Fauna norvegica - online and open access. Fauna norvegica 30: 1-3.

doi: 10.5324/fn.v30i0.669. Published online: 2010-12-21.

Museum of Natural History and Archaeology

Norwegian University of Science and Technology

NO-7491 Trondheim

Norway

E-mail: torkild.bakken@vm.ntnu.no

From this volume on, Fauna norvegica has taken several measures to be an electronic journal. Although we retain the printed volume we will now be fully electronic. One of our aims is to present descriptions of new taxa, hence we are obliged by the zoological rules of nomenclature to have a certain number of hard copies distributed to libraries, hence we will still publish each volume in print.

Scanning of all back issues has been completed. Volumes will be available open access when each volume is successively placed in the online depository.

\section{Online services}

From our web page hosted at the publisher; NTNU Museum of Natural History and Archaeology we post updates and news. From this page (Figure 1) authors can access online services for submission and have access to free open access articles.

Submission of articles is now entirely online. Fauna norvegica uses the "Open Journal Systems" software that enables the authors to track their manuscript through the review-process. To be able to submit a manuscript the author will have to be registered as a user. The author can $\log$ in and upload a revised version of the manuscript after the review (Figure 2). We believe this system will speed up the publication process.

Keeping online services give us the opportunity to publish articles online shortly after the galley proof has been approved by the authors. The printed volume is generally published annually in December. To keep track of articles published online we have introduced DOI identifiers from this volume.

\section{Open access}

Fauna norvegica has been open access for some time. We expand this by changing our copyright policy to apply a Creative Commons License (see webpage for details). By doing this we encourage authors to publish their articles in their personal webpages and institutional archives, hence to disseminate research results widely.

The journal's open access policy and also the introduction of the Open Journal Systems software makes published articles more available to indexing bodies. Upon publication of a volume data is fed to for example Directory of Open Access Journals (DOAJ), CrossRef and Google Scholar, in addition to standard reference databases the journal has used for a long time.

\section{Editorial board}

We are pleased to welcome Dr Jussi Evertsen to the editorial board. Evertsen's main responsibility will be in manuscripts on molluscs and marine issues in general. 


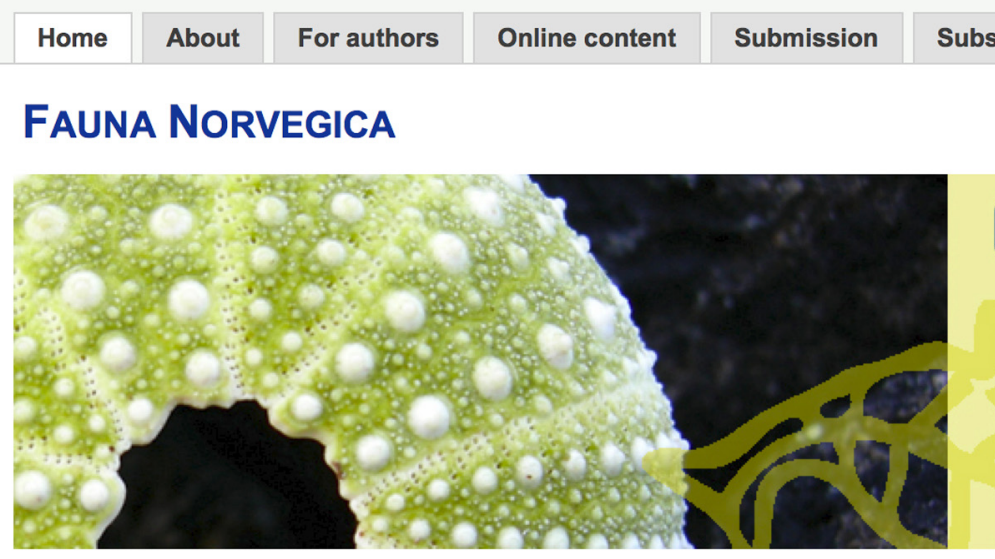

Fauna norvegica

Sep 23rd, 2009 by Torkild Bakken

\section{Fauna norvegica}

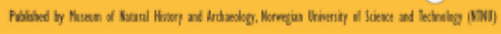

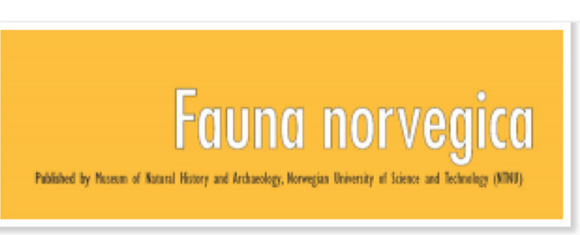

Fauna norvegica is an international journal focusing

on Nordic fauna. In addition

to faunistic studies,

contributions concerning

systematics and taxonomy,

biogeography, biodiversity in order to describe abundance and distribution, as well as methodological development, are welcome. Submitted manuscripts will be considered for publication after peer review.

Fauna norvegica ISSN: 1502-4873 (printed), 1891-5396 (electronic)

Published by NTNU Museum of Natural History and Archaeology

Posted in Info | No Comments »

\section{Back issues on-line}

Jul 9 th, 2010 by Torkild Bakken

Back issues of Fauna norvegica back to volume 1 will be made available open access. Scanning of single papers have started, and will be made available in the journal's open access pages as the work progress. Continue Reading "

Posted in Info | No Comments »
Feed on Mosts QComments

NTNU

Vitenskapsmuseet

\section{Archives}

July 2010 (1)

March 2010 (2)

January 2010 (2)

September 2009 (1)

\section{Categories}

Info (4)

New volume published (2)

\section{Tag Cloud Caudofoveata $\mathrm{fiSh}_{\text {Gastropoda }}$ Mollusca ${ }_{\text {Rotifera }}$ Teleostei}

\section{Pages \\ About \\ For authors \\ Online content \\ Submission \\ Subscription}

Figure I. An image from the web page of Fauna norvegica presenting news, and directions for using the submission tools. From this page access to all content is given when following the link to the online depository. 


\section{Fandina norveginca}

@ NTNU

Vitenskapsmuseet

HOME ABOUT USER HOME SEARCH CURRENT ARCHIVES SUBMIT ARTICLE

Home $>$ User $>$ Author $>$ Submissions $>\# 644>$ Summary

\#644 Summary

SUMMARY REVIEW EDITING

Submission

Authors Jussi Evertsen, Torkild Bakken

Title Testpaper 1 - test av submit funksjonene i Fauna norvegica

Original file 644-2451-1-SM.DOCX 2010-08-20

Supp. files 644-2452-1-SP.JPG 2010-08-20

-20 ADD A SUPPLEMENTARY FILE

Submitter Jussi Evertsen

Date submitted August 20, 2010-11:55 AM

Section Articles

Editor Torkild Bakken E:

Author comments

Test av submit funksjonen i Fauna norvegica

CURRENT ISSUE

\begin{tabular}{|l|l|}
\hline BTOM & 1.0 \\
\hline
\end{tabular}

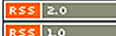

OPEN JOURNAL SYSTEMS

Journal Help

USER

You are logged in as..

jussievertsen

- My Journals

- My Profile

AUTHOR

Submissions

- Active (1)

- Archive (0)

- New Submission

\section{Status}

$\begin{array}{ll}\text { Status } & \text { In Editing } \\ \text { Initiated } & 2010-11-28 \\ \text { Last modified } & 2010-11-28\end{array}$

JOURNAL CONTENT

Search

All

Search

Figure 2. An example showing how authors can navigate through the review process of the submitted manuscript (encircled in black). For details the journal's webpages should be consulted. 